bestemte kasser (hvorfor Israel også bliver nødt til at lave en særlig kategori til Rousseau, og til dels også til Kant). Værket giver imidlertid et interessant nyt blik på en afgørende epoke i den europæiske (og verdens) historie og lokaliserer ikke mindst en betydningsfuld og indflydelsesrig radikal tradition, der ikke før er behandlet så grundigt. Det bliver dermed et must for alle, der beskæftiger sig med oplysningstiden. Men pas på: Den lettilgængelige og korte stil gør, at Israels pointer ofte fremstår uforklarede og postulatoriske, og man drages derfor mod de større og mere udførlige værker - hvilket selvfølgelig er et godt salgstrick.

NANNA KATRINE LÜDERS KAALUND

\section{Darwin på dansk}

Charles Darwin: Arternes Oprindelse ved Naturlig Selektion eller Bevarelse af de bedst tilpassede racer $i$ kampen for tilvarelsen, oversat af Jorn Madsen, forord af Peter C. Kjargaard, Statens Naturbistoriske Museeum, 2009, 388 sider, 249,- kr.

Den 24. november 1859 blev en af alle tiders mest omtalte og diskuterede bøger publiceret. Forfatteren var Charles Darwin, og bogen hed On the Origin of Species by Means of
Natural Selection, or the Preservation of Favoured Races in the Struggle for Life. Hovedargumentet i Origin var, at arterne ikke var blevet skabt hver for sig, og at mekanismen, hvorved arterne over tid havde forandret sig, var naturlig selektion. I indledningen til Origin skriver Darwin således, at "Jeg er overbevist om, at arter ikke er uforanderlige, men at de, der hører til samme slægt, nedstammer fra andre, oftest uddøde arter, på samme måde som en art kan give ophav til en række varieteter."

Origin blev udsolgt på udgivelsesdagen og skabte øjeblikkelig stor debat $i$ alle samfundslag, en debat, der stadig er aktuel i det 21. århundrede. Darwin var dog ikke den første, der havde fremlagt en teori om livets udvikling. I 1844 blev værket Vestiges of the Natural History of Creation udgivet af en anonym forfatter. Vestiges vakte en enorm furore og modtog megen kritik for sit indhold, der i høj grad manglede videnskabelig underbygning. Den negative modtagelse af Vestiges var uden tvivl medårsag til, at Darwin ventede så længe med at publicere sine idéer, som han gjorde. Omkring samtidig med udgivelsen af $V$ estiges havde Darwin udfærdiget et længere manuskript, der indeholdt en skitse af hans teori. Dette manuskript ville han ikke publicere endnu, men fik det arrangeret således, at det ville blive offentlig- 
gjort i tilfælde af, at han døde, før han fik færdiggjort sit planlagte flerbindsværk.

Over den næste årrække ville Darwin fortsætte med at undersøge, udfærdige og sammenfatte de mange emner, som han mente var nødvendige for at præsentere et så overbevisende argument som muligt. Dette ville han øjensynligt have fortsat med i meget længere tid, hvis han ikke i 1858 havde modtaget et brev fra Alfred Russel Wallace. Wallace havde under en ekspedition i Sydamerika fået den samme idé om udvikling ved naturlig selektion som Darwin. Dette var forståeligt nok et chok for Darwin, og han frygtede, at han ville miste æren for den teori, han så længe havde arbejdet på. Det blev i samarbejde med Charles Lyell og Joseph Hooker arrangeret, at Darwins oprindelige manuskript og Wallaces brev blev læst op sammen til et møde i Linnean Society i London d. 1. juli 1858. Således fik begge æren, men det var tydeligt, at Darwin var kommet på idéen længe før Wallace. Origin blev af Darwin kaldt for et uddrag, der nødvendigvis måtte være mangelfuldt, og blev aldrig til det flerbindsværk, han havde forestillet sig, at det skulle have været.

Origin er siden sin udgivelse i 1859 blevet oversat til mange sprog og forelagdes første gang på dansk som 9 subskriptionshæfter under titlen Naturlivets Grundlove. Et forsog på at havde Enheden $i$ den Organiske Verden i 1871. Oversættelsen var lavet efter originalens femteudgave af botanikeren J.P. Jacobsen. Jacobsens noget kreative oversættelse af titlen blev efter kritiske anmærkninger ændret, da Origin udkom i en samlet udgave i 1872, nu under titlen Om Arternes Oprindelse ved Kvalitetsvalg eller ved de heldigst stillede Formers Sejr i Kampen for Tilvarelsen. Har man, som jeg, forsøgt at give sig $\mathrm{i}$ kast med Jacobsens oversættelse, har man nok også, som jeg, måttet erkende, at den prosaiske skriveform, der fungerer så glimrende i eksempelvis Fru Marie Grubbe og Et Skud $i$ Tagen, gør læseoplevelsen til noget af en udfordring i Om Arternes Oprindelse.

Det var således med stor fornøjelse, at jeg læste Jørn Madsens særdeles gode nyoversættelse med titlen Om Arternes Oprindelse ved Naturligt Selektion, eller bevarelse af de bedst tilpassede racer $i$ kampen for tilvarelsen. Jørn Madsen har, i langt højere grad end Jacobsen, forholdt sig tro mod den engelske originaludgave, men har for klarheds skyld oversat forskellige fagudtryk til deres moderne navne. Oversættelsen indeholder et kort forord af formidlingschef ved Statens $\mathrm{Na}$ turhistoriske Museum, Hanne Strager, en god introduktion til Dar- 
wins liv og omstændighederne ved udgivelsen af Origin af professor Peter C. Kjærgaard og en kommentar til oversættelsen af Jørn Madsen selv. Herudover indeholder oversættelsen en vældig brugbar personliste, som kan gøre det lidt lettere at holde rede på, hvem Darwin refererer til, en litteraturliste og et stikordsregister.

Darwin lavede mange ændringer $\mathrm{i}$ de forskellige udgaver som svar på kritikken, kommentarerne og debatten i hans samtid. Den nye danske oversættelse er lavet ud fra førsteudgaven, og dette har den store fordel, at man undgår de mange korrektioner og tilføjelser, der for de fleste moderne læsere vil være irrelevante. Her kan det tilføjes, at Jørn Madsen i sin oversættelse har været meget tro mod Darwins originale værk i den forstand, at der ikke er blevet korrigeret i de data og ved de forklaringer, hvor det senere har vist sig, at Darwin ikke var på helt rette spor. Darwin og hans samtid kendte ikke til gener, hvorfor den ene af to primære videnskabelige kritikker af Origin omhandlede mekanismen for oprindelsen og bevarelsen af de favorable variationer. Således blev den lamarckistiske mekanisme om arvelighed af erhvervede egenskaber i højere og højere grad taget som supplement til darwinismens udviklings- og selektionsidéer i 1870erne og 1880erne. I 1930erne blev genetikken og evolutionslæren endeligt forenet $i$ den såkaldte neodarwinistiske syntese. Den anden primære kritik gik på spørgsmålet om jordens alder, der var et meget debatteret tema.

De i Darwins teori indeholdte metaforer om kamp og selektion har vist sig at være så bøjelige, at de kan anvendes i vidt forskellige sammenhænge, og tænkere med vidt forskellige politiske og sociale holdninger har retfærdiggjort deres tanker i darwinismen. De forskellige evolutionsidéer, som f.eks. teistisk evolution og lamarckismen, kan beskrives som stadier i fremkomsten af ikke-, pseudo- og anti-darwinistiske evolutionsfilosofier med et mål om at bevare en tese med en art determinisme eller retning, enten fra Gud eller naturen. Stadig i dag findes der mange myter om, hvad Darwins teori egentlig gik ud på, hvad der blev debatteret i hans samtid og hvordan udviklingsteorien siden har ændret sig. Evolution er stadig et emne, der bliver debatteret vidt, men det er en debat, der ofte er kendetegnet af ringe almen viden om evolution og om Darwins oprindelige teori. Med nyoversættelsen har man således mulighed for at stifte bekendtskab med Darwins oprindelige idé i et lettilgængeligt og letforståeligt dansk. 